\title{
Thrombotic microangiopathy (TMA) in a patient treated with antiviral therapy for hepatitis $C$
}

\author{
Rhys Evans, ${ }^{1}$ Mathena Pavan, ${ }^{2}$ Deepak Suri, ${ }^{2}$ Mark Harber ${ }^{1}$
}

${ }^{1}$ UCL Centre for Nephrology, London, UK

${ }^{2}$ Whittington Hospital, London, UK

\section{Correspondence to}

Dr Rhys Evans,

rhysdrevans@gmail.com

Accepted 17 March 2014
CrossMark

To cite: Evans $R$, Pavan $M$, Suri D, et al. BMJ Case Rep Published online: [please include Day Month Year] doi:10.1136/bcr-2013203290

\section{DESCRIPTION}

A 53-year-old woman presented to the emergency department having collapsed in the hepatology outpatient unit. She had been started on peginterferon- $\alpha$ (180 $\mu \mathrm{cg}$ subcutaneously weekly), ribavirin $(600 \mathrm{mg}$ twice daily) and telaprevir (750 mg thrice daily) for treatment of hepatitis $C$ (genotype 1) 12 weeks prior to admission. The treatment had been complicated by a rash, which was responding to topical steroids but had been otherwise well tolerated with undetectable hepatitis C RNA at 4 weeks.

She described a 1-week history of fatigue, nausea and vomiting. She had a diffuse maculopapular rash extending from her trunk to her limbs but the examination was otherwise unremarkable. Her creatinine had risen from a normal baseline to $444 \mu \mathrm{mol} / \mathrm{L}$, with low haemoglobin $(6.4 \mathrm{~g} / \mathrm{dL})$ and platelets $\left(88 \times 10^{9} / \mathrm{L}\right)$. Her urinalysis was positive for blood $(1+)$ and protein $(3+)$. She had an elevated lactate dehydrogenase (LDH) (1147 IU/L), undetectable haptoglobins and red cell fragments on blood film.

Renal biopsy demonstrated microthrombi and fragments in the glomeruli and small vessels (figure 1) and a diagnosis of thrombotic microangiopathy (TMA), thought to be a complication of her hepatitis C treatment, was made. She had a

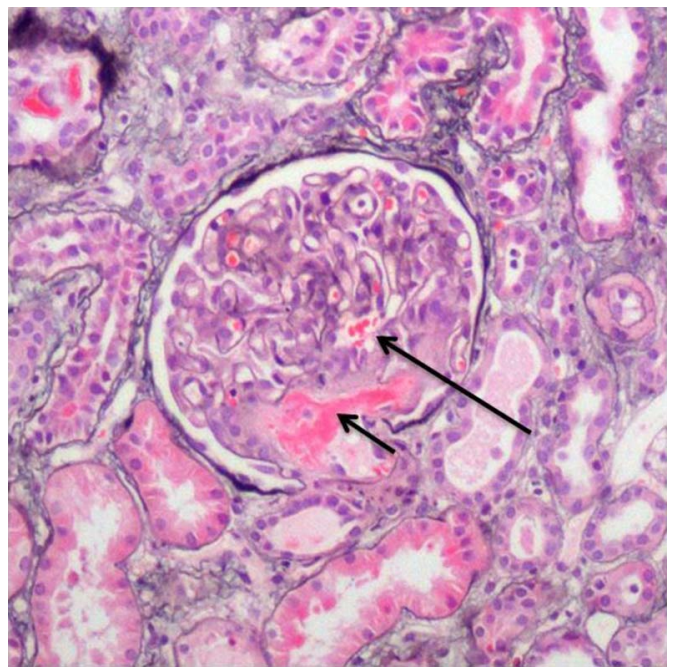

Figure 1 Photomicrograph of renal biopsy demonstrating microthrombi within capillary loops (long arrow) and fibrin deposition (short arrow) (H\&E stain, $\times 100$ ). negative screen for other secondary causes of TMA.

Her antivirals were discontinued and she was treated with seven sessions of plasma exchange. This resulted in complete resolution of her acute kidney injury and normalisation of her platelet count.

While TMA complicating interferon treatment of hepatitis $\mathrm{C}$ has been documented, ${ }^{1}$ this is the first description of TMA complicating triple therapy. Telaprevir is an inhibitor of the hepatitis C NS3/4A serine protease, which is required for viral replication. Inteferon and ribavarin may induce TMA through an immunomodulatory effect. There is little data or evidence to suggest a pathogenic mechanism through which the protease inhibitor telaprevir could induce the event. It may be that it has a direct modulatory effect on endothelial function.

\section{Learning points}

Thrombotic microangiopathy (haemolytic uraemic syndrome) is characterised by acute kidney injury, mild-to-moderate haematoproteinuria, consumed platelets and evidence of mechanical intravascular haemolysis (undetectable haptoglobins, raised lactate dehydrogenase, red cell fragments on blood film).

- Medications may trigger thrombotic microangiopathy, including interferon- $\alpha$ and protease inhibitors (eg, telaprevir).

- Treatment in this context should consist of stopping precipitant medications and consideration of plasma exchange.

Contributors All authors contributed equally to the clinical care of the patient. RE prepared the manuscript with reviews from MP, DS and $\mathrm{MH}$.

\section{Competing interests None.}

Patient consent Obtained.

Provenance and peer review Not commissioned; externally pee reviewed.

\section{REFERENCE}

1 Iskander D, Wickremasinghe M, Bain B. Thrombotic microangiopathy complicating pegylated interferon treatment of hepatitis C infection. Am J Hematol 2011;86:859. 


\section{Images in...}

Copyright 2014 BMJ Publishing Group. All rights reserved. For permission to reuse any of this content visit http://group.bmj.com/group/rights-licensing/permissions.

BMJ Case Report Fellows may re-use this article for personal use and teaching without any further permission.

Become a Fellow of BMJ Case Reports today and you can:

- Submit as many cases as you like

- Enjoy fast sympathetic peer review and rapid publication of accepted articles

- Access all the published articles

- Re-use any of the published material for personal use and teaching without further permission

For information on Institutional Fellowships contact consortiasales@bmjgroup.com

Visit casereports.bmj.com for more articles like this and to become a Fellow 